\title{
Unless Otherwise Indicated: A Survey of Copyright Statements on Digital Library Collections
}

\author{
Melanie Schlosser
}

This study examines the copyright statements attached to digital collections created by members of the Digital Library Federation. A total of 786 collections at twenty-nine institutions were examined for the presence of statements and their content evaluated for common themes. Particular attention was paid to whether the institutions in question are meeting their obligation to educate users about their rights by including information about fair use and the public domain. Approximately half the collections surveyed had copyright statements, and those statements were often difficult to distinguish from terms of use and were frequently vague or misleading.

\section{Introduction \\ Problem Statement}

The growing prevalence of digital collections has created new territory for libraries and for copyright law. The need to comply with copyright law while selecting materials for digitization and creating access policies for the digital objects is widely acknowledged. ${ }^{1}$ Once the collection is digitized and mounted online, however, there is another pressing need-providing end users with the information they need to make legal use of the objects.

There are well-documented and widely accepted guidelines regarding the library's responsibility to provide copyright information in the context of photocopying and interlibrary loan, ${ }^{2}$ but no such consensus has emerged for the necessary presence or content of copyright statements on digital collections.
Attempting to follow the same guidelines is problematic. Digital collections are substantively different from the photocopies allowed under Section 108 of the Copyright Act, which allows libraries to provide copies to patrons upon request under certain conditions. Digital collections are, rather, carefully selected and organized groups of materials to which the library provides persistent intellectual access. In this sense, they are more closely akin to the books in the stacks and the papers in the archives. The ease of copying in the digital environment, however, has made these collections vulnerable to the same issues that provoked the regulation of photocopies - for example, the possibility of widespread and systematic copying. Given this, it is appropriate that libraries communicate copyright information to the users of these collections, as they do to patrons requesting

Melanie Schlosser is Assistant Professor at The Ohio State University Libraries; e-mail: schlosser.40@ osu.edu. 
photocopies. To date, there has been no systematic study of copyright statements on library-generated digital collections, so it is difficult to assess how often they are present and what sort of information they convey to the user. This paper will argue that libraries have a responsibility to provide copyright information in the digital realm and that that responsibility extends specifically to promoting the public domain and educating users about fair use. It will examine the digitized collections (copyrighted, public domain, and mixed) created by members of the Digital Library Federation to determine how often copyright statements are present and analyze the content of those statements for common themes. The data will shed light on how well libraries are meeting their obligations in this realm.

\section{Background \\ Studying Copyright Information}

In spite of the recent explosion of legal and technological action surrounding copyright of digital objects, surprisingly little attention has been paid to the copyright information presented to users in the digital environment. Warwick and Zie's ${ }^{3}$ study of users' perceptions of copyright and electronic forms reveals widespread unfamiliarity with and a lack of concern about copyright restrictions. The users involved had difficulty locating copyright information associated with electronic objects and were willing to devote very little time to finding it. Studies of copyright and digital library collections mostly center on access policies and the need to comply with copyright law when digitizing collections and mounting them online. Meyyappan, Chowdhury, and Foo's ${ }^{4}$ broad-based survey of library digital collections considers access restrictions along with content, user interface, and other variables. In the closest parallel, Koulouris \& Kapidakis ${ }^{5}$ analyze the access policies of 10 university digital libraries around the world, including such issues as when libraries grant offsite access to collections and when they put certain use terms on them (for instance, private reproduction allowed with credit). Information about the policies was gathered from a variety of sources, including copyright statements, and no distinction was made between use restrictions based on copyright ownership and general terms of use. The collections analyzed include licensed databases as well as library-digitized collections, and the aim of the study is to assist libraries in developing access policies based on copyright status and digitized or born-digital status, with common practice as the guide.

\section{Library Copyright Requirements in the Physical Environment}

Most discussion of the requirements of libraries in complying with and communicating information about copyright law revolves around section 108 of the U.S. Copyright Act. ${ }^{6}$ Commonly known as the library copying provision, section 108 lays out conditions under which libraries may embark on copying activities that would otherwise be considered infringement. Bernfeld ${ }^{7}$ provides a detailed history of section 108 , including the rights it establishes beyond fair use and the implications for self-service photocopying in libraries. Hilyer ${ }^{8}$ discusses the implications of section 108 and the National Commission on New Technological Uses of Copyright Works (CONTU) ${ }^{9}$ guidelines on interlibrary loan activities, including how many copies can be legally made and what copyright information must be communicated to the recipients.

\section{Library Copyright Requirements in the Digital Environment}

The proliferation of digital content has steered libraries into new territory with regard to copyright, including supporting distance education and digitizing special collections for access and preservation purposes. Acknowledging that the traditional library copying provisions no longer adequately address the needs of libraries, changes to the law were sought and made. Davis ${ }^{10}$ discusses the TEACH 
$A c t^{11}$ and suggests a model for complying with copyright in the online course environment. In 2005, the Library of Congress convened the Section 108 Study Group to reexamine the law and make recommendations for its continued relevance in the digital environment. The Group released a report in $2008,{ }^{12}$ recommending a number of changes to the law.

At the same time, libraries have grappled with their role as publishers of digital content in the form of digitized locally held collections. Brancolini ${ }^{13}$ provides a model for selecting collections for digitization, of which investigation of copyright restrictions is a fundamental part. Lopatin ${ }^{14}$ surveys the literature on library digitization projects and acknowledges the ubiquity of copyright concerns in creating digital collections. For libraries uncertain about the ownership of their digitized collections, Bridgeman v. Corel $^{15}$ establishes the need for a minimal level of creative input to assert copyright protection. It identifies as "slavish copies" the faithful reproductions of two-dimensional works created by digitization activities, which means these reproductions are not eligible for additional copyright protection.

\section{Why Put Copyright Statements on Digital Collections?}

Besides the desire to mitigate liability for end-user infringement, there are compelling reasons for libraries to provide information about the copyright status of their digitized collections. Educating users about copyright is often considered a responsibility of libraries. ACRL Standards for Libraries in Higher Education ${ }^{16}$ advise librarians to collaborate with teaching faculty to teach students skills in "information evaluation, critical thinking, intellectual property, copyright, and plagiarism." A number of academic libraries, including those at North Carolina State University, ${ }^{17}$ University of California, ${ }^{18}$ University of Texas, ${ }^{19}$ Columbia University, ${ }^{20}$ University of Washington, ${ }^{21}$ Duke University, ${ }^{22}$ and the Ohio State Universi- ty, ${ }^{23}$ have established copyright education Web sites that touch on issues pertinent to higher education. Harris ${ }^{24}$ provides guidelines for establishing a copyright education program in a university setting, with an emphasis on complying with the law. Wagner ${ }^{25}$ describes the library's role as a copyright information resource for faculty on campus.

If section 108 is the oil that keeps the library machine running smoothly, then section $107,{ }^{26}$ the fair use doctrine, is the safety valve that prevents the intellectual property system from breaking down. Fair use "permits the reproduction, for legitimate purposes, of material taken from a copyrighted work to a limited extent that will not cut into the copyright owner's potential market for the sale of copies." ${ }^{27}$ The uses that fair use makes possible, such as quotation and criticism, are essential for the "progress of science and the useful arts." ${ }^{28}$ Beebe $^{29}$ conducts an empirical study of fair use case law, demonstrating how the fair use defense functions beyond the handful of commonly cited cases, and examines the four factors to see how they are weighed by judges. Much has been written about fair use and its implications in the digital environment. ${ }^{30}$ While users push for more content and functionality at less cost, and copyright holders demand greater technological and legal protection for their works, libraries are often caught in the middle. ${ }^{31}$ Digital Rights Management (DRM) technologies, the frequent application of click-through licenses on digital content, and fear of widespread piracy have raised fears that fair use rights are being eroded. ${ }^{32}$ As institutions that rely heavily on fair use and are concerned with access to information for all users, libraries have risen to its defense. The American Library Association (ALA) Washington Office advocates regularly on fair use issues. ${ }^{33}$ In 2007, the Computer and Communications Industry Association issued a report describing libraries as one of the 'core' fair use industries and detailing their contributions to the U.S. economy. ${ }^{34}$ 
Libraries have an equally large interest in, and responsibility to, the public domain, which consists of works that have passed out of copyright protection or were not eligible for it. Public domain items can be used in any way, without permission from a copyright holder. Recent legal developments, including Eldred v. Ashcroft, ${ }^{35}$ which upheld the Sonny Bono Copyright Term Extension Act, ${ }^{36}$ have generated concern about the shrinking of the public domain and have inspired libraries to advocate on its behalf. The ALA and the American Association of Law Libraries (AALL) have both shown support for the Public Domain Enhancement Act of 2005; $;^{37}$ the AALL justifies its support by asserting that "Libraries and library patrons value and depend on the public domain." 38 The Library Copyright Alliance includes as one of its goals for the Library-Related Principles for the International Development Agenda of the World Intellectual Property Organization, "A robust and growing public domain to provide new opportunities for creativity, research, and scholarship." 39

Libraries' role as stewards of the public domain has only been enhanced by the rise in digital content. Copyright considerations often constrain libraries embarking on a digitization program to limit their activities to fall within the scope of fair use or to focus on public domain materials. These digitized public domain collections are beneficial to users, who gain access to materials that would otherwise be unknown and inaccessible, as well as to libraries, who gain visibility and add value to their Web sites. These digitized collections are not always made freely available to the public. Fyffe and Warner ${ }^{40}$ discuss the propriety of libraries licensing digital rights to their public domain collections to commercial entities. They conclude, "These institutions enjoy public support because they are considered to provide a significant public benefit. It diminishes this benefit to restrict access to the holdings of these institutions, especially when a commercial business is permitted to profit through subscriptions or sales that restrict public access."

\section{Copyfraud}

An extra-legal threat to fair use and the public domain is the practice of attaching false or misleading copyright statements to works - a practice dubbed "copyfraud" by Mazzone. ${ }^{41}$ Because of the weak (and rarely applied) penalties for overreaching copyright claims, it is common for copyright owners to claim rights beyond those allowed by the law and for publishers and other content producers to claim copyright on public domain items. Since public comprehension of copyright law is not strong, such claims can easily dissuade conscientious users from making legal use of the material. Ebbinghouse ${ }^{42}$ introduces the concept to libraries with examples of copyfraud by content producers and of libraries paying for material and uses that should legally be free.

\section{Research Questions}

As institutions subject to the law, it is the responsibility of libraries to provide accurate copyright information about their digitized collections. As stewards of public access to knowledge, and organizations with an educational mission, it is their duty to educate users of their rights and responsibilities under copyright law. As beneficiaries of fair use and the public domain, it is their responsibility to acknowledge these benefits, so that their users may benefit from them as well. It is the goal of this study to determine what information libraries are providing to users of their digital collections via copyright statements. Specifically, it will ask: 1) Are libraries putting copyright statements on their digital library collections? 2) Are they more likely to place statements on collections made up of copyrighted materials, or on those made up of public domain materials? 3) Are there common elements among statements? 4) Do they acknowledge the existence of the public domain and of fair use? 


\section{Methodology \\ Sample}

The sample for this study was the digital collections created by the partners of the Digital Library Federation (DLF). DLF is "a consortium of libraries and related agencies that are pioneering the use of electronic-information technologies to extend collections and services, ${ }^{43}$ whose goals are "identifying standards and 'best practices' for digital collections and network access, coordinating leading-edge research and development, and helping start projects and services that libraries need but cannot help individually." ${ }^{44}$ DLF has 37 partners: mainly U.S. academic libraries, but including a small number of international libraries, U.S. governmentrun libraries, nonprofit organizations, and a public research library. Since copyright laws vary internationally, the sample was limited to U.S. institutions. It was also narrowed to exclude U.S. government institutions and those that do not create their own digital collections. The final sample consisted of 29 institutions that vary widely in size, funding source, and focus. One difficulty in using DLF partners to represent the larger digital library community is that membership in DLF is a significant investment, so its partners skew toward institutions with a significant financial base. However, unlike other aspects of digital library work (software, for example), drafting copyright statements and attaching them to collections does not require a direct financial investment; so using DLF partners as a sample is less problematic in this case. Still, it is a matter for future research to discern what factors influence the presence and content of such statements and how they may differ in other settings.

For each institution, a list of digital collections was identified. For this study, a "digital collection" is defined as any organized collection of digitized objects, such as books, manuscripts, images, and other materials, that is freely available to the public via the World Wide Web. Collections consisting of some freely available items and some restricted items were included, but only the freely accessible items were surveyed. Materials considered out of scope were finding aids, bibliographies, and other guides to nondigitized materials; online "exhibits" made up of images from other collections counted by the survey; and born-digital items. Open-access journals published by the library in question were considered only if they include a digitized archive of print back issues. Since institutional repositories encompass a variety of content, and are frequently a highly visible component of a library's digital collections, they were included. Each collection was only counted once; in cases where two or more institutions in the sample collaborated on a collection that has a single interface, it was included with the collections of the first collaborating institution surveyed. Data were gathered between October 2007 and June 2008; sites, collections, and items that were not accessible due to 404 errors or other problems when first surveyed were examined again at a later time. If the error persisted, they were not considered in the survey.

\section{Copyright Status}

For each collection, a determination was made whether the collection was composed of public domain items, copyrighted items, or a mix of the two. The collection description was examined first. If the collection description was missing or did not contain the relevant information, enough items were examined to reach a determination. Collection contents were considered to be in the public domain if they were published before 1923 or belong to a class of items considered noncopyrightable (for example, works created by employees of the U.S. government, or data sets). Materials created but not published before 1978 are protected until 70 years after the author's death, or 120 years after the creation date for a corporate author. Since determining authorship and death dates was outside the scope of this survey, a generous amount of time 
was allotted -70 years of life followed by 70 years of protection; therefore, unpublished materials created before 1867 were considered to be in the public domain. Following Bridgeman v. Corel, digitized two-dimensional public domain works were considered to remain in the public domain. Items that did not fall under any of these categories were considered to be protected by copyright. Collections that included at least one public domain item, and at least one copyrighted item, were considered "mixed."

\section{Copyright Statements}

For the purposes of this study, a "copyright statement" was considered to be a declaration regarding copyright ownership of digital objects that expressly mentions copyright or provisions of copyright law such as fair use. These statements were not necessarily labeled as such, and could be found anywhere on the collection site (for instance, in the collection description). Conditions of use statements that declared the permitted uses of the item(s) were not considered copyright statements if they did not meet these criteria. Boilerplate institutional or university copyright statements that appear at the bottom of every Web page were considered as applying to the design of the site itself, not to the digitized items, and were not included. Copyright statements on the digitized items themselves (like the title page of a digitized book) were not included. Each site was examined for an institutional or program-level copyright statement. Each collection on the site was then examined for a collection-level statement. If no collection-level statement was found, enough items were examined to answer the questions about the collection. Collections with item-level statements on some items only were counted as having a copyright statement.

Each statement was examined for references to the public domain and/or fair use. References to the public domain were divided into two camps - those that included the words "public domain" and those that implied its existence through phrases such as "no copyright restrictions." The statements were then subjected to content analysis to identify common elements. References to personal and/or educational use of the collections were so common that they were included in the quantitative data along with mentions of fair use and the public domain. Other elements that appeared repeatedly across multiple institutions were identified and then grouped into broad categories ("memes").

\section{Data}

Of the twenty-nine institutions surveyed, twelve had a copyright statement at the

\begin{tabular}{|l|c|c|c|c|c|}
\hline \multicolumn{7}{|c|}{ TABLE 1 } \\
\hline & $\#$ & $\begin{array}{c}\% \text { of } \\
\text { Institutions }\end{array}$ & & $\#$ & $\begin{array}{c}\% \text { of } \\
\text { statements }\end{array}$ \\
\hline \hline Institutions & $\mathbf{2 9}$ & & & & \\
\hline No institutional statement & 17 & $59 \%$ & & & $25 \%$ \\
\hline With institutional statement & $12 *$ & $41 \%$ & $\begin{array}{c}\text { Mention public } \\
\text { domain }\end{array}$ & 3 & \\
\cline { 3 - 6 } & & & Mention fair use & 7 & $58 \%$ \\
\hline $\begin{array}{l}\text { * In Tables 1, 2, 4, 5, and 6, an analysis of the statement contents is presented on the right. The } \\
\text { contents in each category are not mutually exclusive (for example, one of the above statements } \\
\text { could mention both fair use and the public domain), and the statements that do not contain any of the } \\
\text { elements listed are not enumerated. For these reasons, the numbers and percentages on the far right of } \\
\text { each table will not add up to the number of statements examined or 100\%, respectively. }\end{array}$ \\
\hline
\end{tabular}




\begin{tabular}{|l|c|c|l|c|c|}
\hline \multicolumn{7}{|c|}{ Statements on Collections } \\
\hline \hline & $\begin{array}{c}\% \text { of } \\
\text { collections }\end{array}$ & & $\#$ & $\begin{array}{c}\% \text { of } \\
\text { statements }\end{array}$ \\
\hline Collections & 786 & & & & \\
\hline No statement & 330 & $42 \%$ & & & \\
\hline $\begin{array}{l}\text { Link to institutional } \\
\text { statement }\end{array}$ & 54 & $7 \%$ & & & \\
\hline With statement & 402 & $51 \%$ & $\begin{array}{l}\text { Mention public domain } \\
\text { (explicit) }\end{array}$ & 31 & $8 \%$ \\
\cline { 4 - 7 } & & & $\begin{array}{l}\text { Mention public domain } \\
\text { (implied) }\end{array}$ & 9 & $2 \%$ \\
\cline { 4 - 7 } & & & Mention fair use & 37 & $9 \%$ \\
\cline { 3 - 7 } & & & $\begin{array}{l}\text { Mention personal/ } \\
\text { educational use }\end{array}$ & 268 & $67 \%$ \\
\hline
\end{tabular}

institutional level. Of those twelve statements, seven mentioned fair use and only three mentioned the public domain (table 1).

Of the 786 collections examined, $28 \%$ consisted entirely of copyrighted items, $28 \%$ contained a mix of copyrighted and mixed items, and $41 \%$ were composed entirely of public domain items Approximately half of the collections surveyed had copyright statements at the collection or item level. The other half had no statement or had only a link to an institutional statement (table 2).

It is interesting to note that the presence or absence of a copyright statement was not significantly affected by the copyright status of the collection. Mixed collections had the highest

\begin{tabular}{|l|c|c|}
\hline \multicolumn{3}{|c|}{ TABLE 3 } \\
Copyright Status of Collections \\
\hline \hline & $\#$ & $\begin{array}{c}\% \text { of } \\
\text { collections }\end{array}$ \\
\hline Collections & $\mathbf{7 8 6}$ & \\
\hline Copyrighted collections & 224 & $28 \%$ \\
\hline Mixed collections & 224 & $28 \%$ \\
\hline Public domain collections & 325 & $41 \%$ \\
\hline $\begin{array}{l}\text { Insufficient information } \\
\text { to determine status }\end{array}$ & 15 & $2 \%$ \\
\hline
\end{tabular}

percentage of statements (table 5) and copyrighted collections the lowest (table 4), but they all hovered around 50 percent. There was also a parallel between the percentage of statements on copyrighted collections that mentioned fair use (table 4) and the percentage on public domain collections that explicitly mentioned the public domain (table 6)-both 8 percent. Some mention of personal and/or educational use was consistently the most common of the elements recorded -67 percent overall (table 2), ranging from 53 percent on copyrighted and mixed collections (tables 4 and 5) to 86 percent on public domain collections (table 6). The difference between copyrighted and public domain collections on this parameter is interesting, since the closest parallel in the copyright law, fair use, only applies to copyrighted materials.

No institution was entirely consistent in its application of copyright statements-each had at least one collection with a statement and one without.

\section{Analysis}

Content analysis of the statements revealed a number of elements that appeared often enough to merit consideration. They have been labeled 


\begin{tabular}{|c|c|c|c|c|c|}
\hline \multicolumn{6}{|c|}{$\begin{array}{c}\text { TABLE } 4 \\
\text { Statements on Copyrighted Collections }\end{array}$} \\
\hline & \# & $\begin{array}{c}\% \text { of } \\
\text { collections }\end{array}$ & & \# & $\begin{array}{c}\% \text { of } \\
\text { statements }\end{array}$ \\
\hline Copyrighted collections & 224 & & & & \\
\hline No statement & 108 & $48 \%$ & & & \\
\hline $\begin{array}{l}\text { Link to institutional } \\
\text { statement }\end{array}$ & 8 & $4 \%$ & & & \\
\hline \multirow[t]{4}{*}{ With statement } & \multirow[t]{4}{*}{108} & \multirow[t]{4}{*}{$48 \%$} & $\begin{array}{l}\text { Mention public } \\
\text { domain (explicit)* }\end{array}$ & 3 & $3 \%$ \\
\hline & & & $\begin{array}{l}\text { Mention public } \\
\text { domain (implied)* }\end{array}$ & 2 & $2 \%$ \\
\hline & & & Mention fair use & 9 & $8 \%$ \\
\hline & & & $\begin{array}{l}\text { Mention personal/ } \\
\text { educational use }\end{array}$ & 57 & $53 \%$ \\
\hline
\end{tabular}

"memes" because of their tendency to reappear, often in slightly altered but recognizable forms, within the collections of a single institution and between institutions. Four memes are identified below; each has a brief explanation and examples of the different types of statements that fall within its scope. The example statements have been anonymized, and most are excerpts rather than complete statements.

\section{Meme: The Specific Ownership Statement}

The statement identifies the copyright holder or provides enough information that the user can easily request permission or make use of the object.

Examples:

"(C) [personal name]"

"To obtain permission from the copyright holder for commercial use of any of these images, contact:..."

\section{TABLE 5}

Statements on Mixed Collections

\begin{tabular}{|c|c|c|c|c|c|}
\hline & $\#$ & $\begin{array}{c}\% \text { of } \\
\text { collections }\end{array}$ & & \# & $\begin{array}{c}\% \text { of } \\
\text { statements }\end{array}$ \\
\hline Mixed collections & 224 & & & & \\
\hline No statement & 87 & $39 \%$ & & & \\
\hline $\begin{array}{l}\text { Link to institutional } \\
\text { statement }\end{array}$ & 12 & $5 \%$ & & & \\
\hline \multirow[t]{4}{*}{ With statement } & \multirow[t]{4}{*}{125} & \multirow[t]{4}{*}{$56 \%$} & $\begin{array}{l}\text { Mention public } \\
\text { domain (explicit) }\end{array}$ & 15 & $12 \%$ \\
\hline & & & $\begin{array}{l}\text { Mention public } \\
\text { domain (implied) }\end{array}$ & 3 & $2 \%$ \\
\hline & & & Mention fair use & 23 & $18 \%$ \\
\hline & & & $\begin{array}{l}\text { Mention personal/ } \\
\text { educational use }\end{array}$ & 66 & $53 \%$ \\
\hline
\end{tabular}




\begin{tabular}{|l|c|c|l|c|c|}
\hline \multicolumn{7}{|c|}{ TABLE 6: } \\
\hline \hline & $\#$ & $\begin{array}{c}\% \text { of } \\
\text { collections }\end{array}$ & & $\#$ & $\begin{array}{c}\% \text { of } \\
\text { statements }\end{array}$ \\
\hline $\begin{array}{l}\text { Public domain } \\
\text { collections }\end{array}$ & 325 & & & & \\
\hline No statement & 123 & $38 \%$ & & & \\
\hline $\begin{array}{l}\text { Link to institutional } \\
\text { statement }\end{array}$ & 36 & $11 \%$ & & & \\
\hline With statement & 166 & $51 \%$ & $\begin{array}{l}\text { Mention public domain } \\
\text { (explicit) }\end{array}$ & 14 & $8 \%$ \\
\cline { 4 - 7 } & & $\begin{array}{l}\text { Mention public domain } \\
\text { (implied) }\end{array}$ & 4 & $2 \%$ \\
\cline { 4 - 7 } & & & Mention fair use & 5 & $3 \%$ \\
\cline { 3 - 7 } & & & $\begin{array}{l}\text { Mention personal/ } \\
\text { educational use }\end{array}$ & 143 & $86 \%$ \\
\hline
\end{tabular}

"Copyright has been assigned to the [name of institution]."

"Public domain"

"This database only includes images that are not currently under copyright restrictions."

\section{Meme: The Vague Ownership Statement}

The statement warns that copyright applies or may apply to the object(s) in question but does not provide any specific information about the copyright holder. Claims of "digital copyright" on scanned images have been included in this section, as have specific ownership statements with qualifications.

\section{Examples:}

"Copyright is retained by the original copyright holder"

\section{"[Institution] owns digital rights only"}

"Copyright to most of the original posters has expired, or in the case of governmentproduced posters, was always in the public domain. [Institution] holds copyright to the scanned images."

"Copyright has not been assigned to the [institution]."
"All images of artwork in the [collection] are copyrighted."

"Where applicable, subject to copyright. Other restrictions on distribution may apply."

"The photographs in this collection were taken by photographers working for the U.S. Government. Generally speaking, works created by U.S. Government employees are not eligible for copyright protection in the United States. However, the photographs may be under copyright in some foreign countries, and privacy and publicity rights may apply."

"IMPORTANT: MUSIC PUBLISHED AFTER 1923 IS NOT IN THE PUBLIC DOMAIN. YOU WILL NOT FIND IMAGES FOR MUSIC PUBLISHED AFTER THAT DATE ON THIS SITE."*

*The meaning of this statement is presumably the same as the "Public Domain" statement from the specific ownership statement meme, but it has been included in the vague ownership statement meme because it does not explicitly state that the items are in the public domain.

"Items in the [collection] are protected by copyright, with all rights reserved, unless otherwise indicated." 
"This image may be protected by copyright law."

"Restrictions may exist on reproduction, quotation, or publication."

\section{Meme: What You Can and Can't Do}

The statement sets terms for acceptable use. It can take the form of a license (including Creative Commons licenses) that lists specific conditions and uses, or it may categorically allow or prohibit certain types of use, such as educational or commercial. Often the stated terms of use include citing the source or paying a usage fee.

Examples:

"Materials in the [collection] are in the public domain. No copyright permissions are needed. Acknowledgement of the [collection] as a source for borrowed images is requested."

“Copyright (C) 1998, [personal name]. This edition is the property of the editors. It may be copied freely by individuals for personal use, research, and teaching (including distribution to classes) as long as this statement of availability is included in the text. It may be linked to by Internet editions of all kinds. Scholars interested in changing or adding to these texts by, for example, creating a new edition of the text (electronically or in print) with substantive editorial changes, may do so with the permission of the publisher. This is the case whether the new publication will be made available at a cost or free of charge. This text may not be not be reproduced as a commercial or nonprofit product, in print or from an information server."

"For this collection, permitted nonprofit educational uses include: Classroom projection, Posting on unrestricted educational Web sites, Printouts as personal research notes, Printouts to illustrate course papers or drafts of faculty papers, Projected illustration of presentations at conferences. But do not include: Printed publication in scholarly publications, Printed publication in publicity materials, Commercial uses of any type, Any other uses. All uses (with the exception of classroom and conference projections) should contain the acknowledgement: 'From the [institution]'." "The [institution] hereby grants you a nonexclusive, limited license to use the articles and other materials in the [collection] (the "Content") in accordance with these Terms and Conditions (the "License")..."

"Use of this repository constitutes full acceptance of and agreement to these Terms and Conditions. Users may not remove any copyright, trademark, or other proprietary notices from downloaded materials. Use of any materials or works, in whole or in part, from the repository in any manner that is unlawful or infringes any copyright, trademark, patent, trade secret, or other proprietary right of any party is prohibited."

"[Repository] encourages the fair use of copyrighted material, and you are free to link to content here without asking for permission."

"As the physical rights holder of this material, most of which is in the public domain for copyright purposes, the Library charges a usage fee to license an image for commercial use (defined above)."

"It is the user's sole responsibility to secure any necessary copyright permission to publish documents, texts, and images from any holders of rights in these materials. Use of these materials for publication in any medium also requires the permission of the [institution]."

\section{Meme: Protecting Ourselves and You}

This category encompasses a wide variety of statements, but all deal with the legality of the library's use of the object(s) and/or the need for the user to comply with the law when reusing them.

Examples:

"Efforts by the [institution] to locate an heir of the creator or a holder of the copyright to the materials were unsuccessful. If you know of a verifiable copyright holder for this item or if you have any question regarding the 
publication rights, please contact the [institution] Archives."

"The Library has no information on the status of literary rights in the collection, and researchers are responsible for determining any question of copyright."

"The copyright law of the United States (title 17, United States Code) governs the making of reproductions of copyrighted material. Under certain conditions specified in the law, libraries and archives are authorized to furnish reproductions of materials they hold. One of the specified conditions is that the reproduction is not to be used 'for any purpose other than private study, scholarship or research.'"

"It is the user's sole responsibility to secure any necessary copyright permission to publish documents, texts, and images from any holders of rights in these materials."

"The nature of the [institute]'s Special Collections means that copyright or other information about restrictions may be difficult or even impossible to determine despite reasonable efforts."

"Providing reproductions does not constitute permission to publish or reproduce images in print or electronic form."

"Note that only low-resolution scans (72 dpi with javascript protection) have been used on this site to discourage transmission or reproduction of items beyond that allowed by fair use."

"The [institution] wants to hear from any copyright owners who are not properly identified on this Web site so that it may make the necessary corrections."

"The materials are provided on an 'as is' basis and without warranties of any kind, either express or implied, including any warranties of title, noninfringement of copyright or other rights."

\section{Discussion}

As mentioned above, the examples given are partial statements. The full statements often combine two or more of the memes. An example:

"Single photocopies may be made for research purposes. Permission to publish material from the collection must be requested from the University Archivist. The Library has no information on the status of literary rights in the collection, and researchers are responsible for determining any question of copyright."(Memes: What you can and can't do, Protecting ourselves and you)

There are no statements in the sample that label copyrighted collections as being in the public domain. With that exception, all of the memes above appear on all types of collections. Quite a few public domain and mixed collections had Creative Commons licenses or specific or vague ownership statements, implying that the contents are copyrighted in some way. It was especially common for statements to acknowledge that the institution does not hold the copyright to the original item (either because it had passed into the public domain or because the copyright was held by a third party) but to assert copyright over the digital image. Since digital reproductions of two-dimensional items are not eligible for copyright protection, these claims are disingenuous at best.

\section{Research Questions}

The following are the answers, based on the data and analysis above, to the research questions posed earlier: 1) Libraries are putting copyright statements on some, but not all, of their digital collections; 2) The percentage of collections with attached copyright statements is around 50 for all types of materials. Mixed collections have the highest percentage of statements, and copyrighted collections the lowest, but the difference is minimal; 3) There are, indeed, common elements among statements. They can be grouped, roughly, into four memes: the specific ownership statement, the vague ownership statement, what you can and can't do, and protecting ourselves and you. The assertion that the collection is to be used for per- 
sonal, educational, or research use only is the most common element; 4) Less than 10 percent of the statements examined acknowledge the existence of fair use and/ or the public domain.

\section{Problematic Data}

The data used in this study were problematic in a number of ways. Many of the basic concepts involved are extremely fluid, and somewhat arbitrary distinctions had to be made to create a sample. "Digital collection" could mean a number of things and could include born-digital materials and online exhibits composed of items from other digital collections. The breakdown of copyrighted, mixed, and public domain collections was especially problematic. Digitization projects are often slowed, if not stopped entirely, by the need to conduct extensive research on the copyright status of items published between 1923 and 1978. It is likely that large collections of public domain materials languish undigitized in libraries and archives for just this reason. This study was not immune; constraints on time and resources necessitated the use of very rough guidelines for determining copyright status. Since it focused particularly on information given to users of public domain collections, it was important to be reasonably certain that the set of collections examined was, indeed, public domain. As a result, extremely conservative guidelines were used to determine status; the actual percentage of public domain collections is most likely much higher.

\section{Copyright v. Terms of Use}

The definition of a "copyright statement" used by this study was somewhat arbitrary. Many of the statements examined were buried in collection descriptions or looked more like terms of use statements than copyright statements. The first is a clear barrier for users in need of information. The second, while less obviously a problem, bears serious consideration.

Each meme described above suggests a motive. Some statements are meant to provide the user with the means to make legal use of the items in question; they range from a simple assertion of ownership to detailed information about copyright and fair use. Some are clearly an attempt to indemnify the institution from claims of copyright infringement, either by the institution itself or by its patrons. Many, however, seek to control the ways in which the collections are used. Since this type of statement appears regardless of the copyright status of the items, it makes sense to look for a motive beyond compliance with the law. In a small number of cases, the statement itself identifies a motive for the conditions placed on use. One institution explained that its fees for commercial use of public domain images are necessary to sustain its digitization efforts. Another justified its ban on downloading items by asserting the constantly changing nature of the text in question and the need for a single authoritative source. It is outside the scope of this paper to examine the rationale behind use conditions. It is within the scope, however, to explore the extent to which they are appropriate content for copyright statements.

\section{Conclusion}

The line between copyright and terms of use statements is fuzzy. There is no standard terminology or placement for either type of statement, and it is unlikely that users distinguish between them. Adding to the confusion is the fact that statements that explicitly mention copyright, like the ones considered in this study, are often used to convey terms of use information as well. Users are unlikely to recognize that these terms are not based in copyright law and that they may, in fact, conflict with it.

It seems unlikely that libraries are purposely deceiving users with false or misleading claims of copyright ownership (copyfraud). However, this study presents evidence that, far from educating users about copyright or promoting the public domain, many libraries engaged in digiti- 
zation projects are omitting a key tool for copyright education or using it in ways that undermine users' needs for accurate copyright information. Once again, it is outside the scope of this paper to examine the reasons. It is possible that working knowledge of copyright law in many libraries is not sufficient for grappling with the complexities involved ${ }^{45}$ or that the issue has simply slipped through the cracks as libraries embark on difficult and resource-intensive digitization projects.

It is understandable that many libraries would be hesitant to provide detailed copyright information about their collections. As many of the statements acknowledge, in some cases very little is known about the copyright status or owner of an item, and libraries do not have the resources for exhaustive copyright investigation. That said, the literature suggests that libraries rarely embark upon digitization projects without some investigation into the copyright status of the items involved. To do so would be to open the institution up to an unacceptable level of risk. Assuming that the digitizing library has some copyright information, the more than 40 percent of collections with no copyright statement suggest that they are not consistently sharing it with the end user. Anecdotally, libraries are sometimes reluctant to share anything but the most basic copyright information, out of fear that users will take it as legal advice, opening the library to unwanted risk.

It is easy to sympathize with the desire to minimize legal risk, to protect an income stream, or to control unauthorized uses of library collections. However, there are compelling reasons to provide users with complete and accurate copyright information about digitized collections. The results of this study suggest that it is time for libraries active in digitization projects to examine the issues involved and develop a set of best practices for copyright statements on digital collections. Possible topics include what information belongs in a copyright statement; how to distinguish between copyright statements and other restrictions on use; where to place copyright information and how to label it; and how to provide detailed information while minimizing risk.

\section{Opportunities for Future Research}

It is clear from this study that the copyright status of the collection is not the determining factor in the presence or absence of a copyright statement. It is not clear, however, what factors are most influential. A future study could conduct further quantitative analysis involving data such as when the collections were created and the types of materials presented, along with more indepth profiles of libraries that regularly place statements on their collections and those that do not. Future studies with a methodology similar to this one could use a different sample (such as Association of Research Libraries members) or different definitions of the key concepts involved (such as "digital collection" and "copyright statement"). Libraries with significant copyright education programs could be identified and examined to determine how their education initiatives affect the copyright information given to digital collections users. These and other studies could inform best practices efforts and provide context for libraries that wish to evaluate their application of copyright statements to digital collections.

\section{Notes}

1. Laurie Lopatin, “Library Digitization Projects, Issues and Guidelines," Library Hi Tech 24, no. 2 (2006): 273-89.

2. Lee Andrew Hilyer, "Chapter 5: Copyright in the Interlibrary Loan Department," Journal of Interlibrary Loan, Document Supply E Electronic Reserves 16, no. 1 (2006): 53-64.

3. Warwick, Shelly and Hong Xie. "Copyright Management Information in Electronic Forms: 
User Compliance and Modes of Delivery." Proceedings of the Annual Meeting of the American Society for Information Science 62, (10/31, 1999): 292-301.

4. N. Meyyappan, G. G. Chowdhury, and Schubert Foo, "A Review of the Status of 20 Digital Libraries," Journal of Information Science 26, no. 5 (2000): 337-55.

5. Alexandros Koulouris and Sarantos Kapidakis, "Access and Reproduction of Digital Production University Digital Collections," Journal of Librarianship \& Information Science 37, no. 1 (2005): 25-33.

6. U.S. Copyright Act, U.S. Code 17 (2005), Sec. 108.

7. Betsy A. Bernfeld, "Free to Photocopy? A Legislative History of Section 108, the Library Photocopying Provision of the Copyright Act of 1976," Legal Reference Services Quarterly 25, no. 2 (2006): 1-49.

8. Hilyer, "Chapter 5: Copyright in the Interlibrary Loan Department."

9. National Commission on New Technological Uses of Copyright Works (CONTU), The Final Report of the National Commission on New Technological Uses of Copyrighted Works (CONTU) (Washington, D.C.: Library of Congress, 1979).

10. Hazel M. Davis, "Copyright in the Online Course Environment," Journal of Library Administration 45, no. 3 (2006): 513-15.

11. Technology, Education, and Copyright Harmonization Act, Public Law 107-273, U.S. Statutes at Large 116 (2002): 1910, codified at U.S. Code 17 (2005), Secs. 110(2), 112(f).

12. Section 108 Study Group, The Section 108 Study Group Report (Washington DC: The United States Copyright Office and the National Digital Information Infrastructure and Preservation Program of the Library of Congress, 2008).

13. Kristine Brancolini, "Selecting Research Collections for Digitization: Applying the Harvard Model," Library Trends 48, no. 4 (2000): 783.

14. Lopatin, "Library Digitization Projects, Issues and Guidelines."

15. Bridgeman Art Library, Ltd. v. Corel Corp., 36 F. Supp. 2d 191 (S.D.N.Y. 1999).

16. Association of College and Research Libraries Board of Directors, "ACRL-Standards for Libraries in Higher Education" (Chicago: Association of College and Research Libraries, 2004). Available online at www.ala.org/ala/acrl/acrlstandards/standardslibraries.cfm. [Accessed 11 August 2008].

17. North Carolina State University Office of the Provost, "Copyright Administration" (Raleigh: North Carolina State University). Available online at http://provost.ncsu.edu/copyright/. [Accessed 11 August 2008].

18. University of California Regents, "UC Copyright Website" (University of California). Available online at http://universityofcalifornia.edu/copyright/usingcopyrightedworks.html. [Accessed 11 August 2008].

19. Georgia K. Harper, “Copyright Crash Course” (Austin, Tex.: University of Texas Libraries). Available online at http://copyright.lib.utexas.edu/. [Accessed 11 August 2008].

20. Columbia University Libraries/Information Services, "Copyright Advisory Office" (New York: Columbia University. Available online at www.copyright.columbia.edu/. [Accessed 11 August 2008].

21. University of Washington, "UW Copyright Connection" (Seattle, Wash.: University of Washington). Available online at http://depts.washington.edu/uwcopy/. [Accessed 11 August 2008].

22. Duke University Libraries, "Scholarly Communications @ Duke" (Durham, N.C.: Duke University Libraries). Available online at http://library.duke.edu/blogs/scholcomm/. [Accessed 11 August 2008].

23. The Ohio State University Libraries, “The Copyright Help Center @ OSU” (Columbus, Ohio: The Ohio State University). Available online at http://library.osu.edu/sites/copyright/. [Accessed 11 August 2008].

24. Lesley Ellen Harris, "Some Quick Guidelines for Defining Public-Domain Works," Information Outlook 11, no. 4 (2007): 38-39.

25. Victoria H. Wagner, "Processing Reserves, Seeking Permissions and Engaging the Campus: How the Library Serves as the Copyright Touchstone," Journal of Interlibrary Loan, Document Delivery \& Electronic Reserves 18, no. 2 (2008): 247-54.

26. U.S. Copyright Act, U.S. Code 17 (2005), Sec. 107.

27. Abe A. Goldman, "Copyright As It Affects Libraries: Legal Implications," in Encyclopedia of Library and Information Science. Eds. Allen Kent and Harold Lancour (New York: Dekker, 1971), vol. 6,72 .

28. U.S. Constitution, art. 1 , sec. 8 , cl. 8 .

29. Beebe Barton, "An Empirical Study of U.S. Copyright Fair Use Opinions, 1978-2005," University of Pennsylvania Law Review 156, no. 3 (Jan. 2008): 549-624.

30. Melanie Schlosser, "Fair Use in the Digital Environment: A Research Guide," Reference and 
User Services Quarterly 46, no. 1 (2006): 11-17.

31. Henry Carter, "Copyright, Permissions and Fair use in Interlibrary Loan and Electronic Reserve: Introduction," Journal of Interlibrary Loan, Document Delivery \& Electronic Reserves 18, no. 1 (2007): 1-6.

32. Lee S. Strickland, “Copyright's Digital Dilemma Today: Fair Use or Unfair Constraints? Part 2: The DMCA, the TEACH Act and Other E-Copying Considerations," Bulletin of the American Society for Information Science \& Technology 30, no. 2 (Dec. 2003/Jan. 2004): 18-23; George H. Pike, "The Value of Fair Use," Information Today 24, no. 11 (Dec. 2007): 17-21.

33. American Library Association, "Digital Rights Management and Libraries," available online at www.ala.org/ala/washoff/woissues/copyrightb/digitalrights/digitalrightsmanagement. cfm [accessed 11 August 2008]; American Library Association, "Copyright: Fair Use Legislation," available online at www.ala.org/ala/washoff/woissues/copyrightb/fairuseleg/fairuselegislation. cfm [accessed 11 August 2008]; American Library Association, "Fair Use and Electronic Reserves," available online at www.ala.org/ala/washoff/woissues/copyrightb/fairuseandelectronicreserves/ ereservesFU.cfm [accessed 11 August 2008].

34. Computer and Communications Industry Association, "Copyright" (Washington DC: Computer and Communications Industry Association, 2007). Available online at www.ccianet. org/copyright.html. [Accessed 11 August 2008].

35. Eldred v. Ashcroft, 537 U.S. 186 (2003).

36. Sonny Bono Copyright Term Extension Act, Public Law 105-298, 112 stat. 2827 (1998).

37. Public Domain Enhancement Act of 2005, H.R. 2408, 109th Cong.

38. American Association of Law Libraries, "Copyright Term Extension Act (CTEA)" (Washington DC: American Association of Law Libraries, 2007). Available online at www.aallnet.org/ committee/copyright/pages/issues/ctea.html. [Accessed 11 August 2008].

39. Library Copyright Alliance, "Library-Related Principles for the International Development Agenda of the World Intellectual Property Organization" (Washington DC: Library Copyright Alliance, 2004). Available online at www.librarycopyrightalliance.org/wipo.htm. [Accessed 11 August 2008].

40. Richard Fyffe and Beth Forrest Warner, "Where the Giants Stand: Protecting the Public Domain in Digitization Contracts with Commercial Partners," Journal of Library Administration 42, no. 3 (2005): 83-102.

41. Jason Mazzone, “Copyfraud," New York University Law Review 81 (2006): 1026-100. 40.

42. Carol Ebbinghouse, "'Copyfraud' and Public Domain Works," Searcher 16, no. 1 (Jan. 2008):

43. Digital Library Federation, "Digital Library Federation." Available online at www.diglib. org/. [Accessed 11 August 2008].

44. David Seaman and Jerry George, "The Digital Library Federation in America: A Portrait," Zeitschrift Für Bibliothekswesen Und Bibliographie 50, no. 3 (2003): 124-30.

45. K. Matthew Danes, "Library Schools and the Copyright Knowledge Gap (Cover Story)," Information Today 23, no. 2 (2006): 1-15. 